\title{
Northern Voices of the Great War: Personal Perspectives and Narratives from Northern British Columbians
}

\author{
Maureen L. Atkinson \\ University of Northern British Columbia
}

\begin{abstract}
The Great War "ruined everything," according to northern British Columbia resident Vicky (Aldous) Sims in a CBC interview from the mid 1960s. A powerful statement to be sure, but is it a true or accurate reflection? The following article features the voices and perspectives of northern British Columbians, to frame their lived experiences within the wider Canadian historical context of the First World War. As the perspectives and memories of these citizens suggest, the war touched every aspect of life even in the most isolated parts of the province; from the cost of basic food stuffs and supplies, to the demands of volunteerism and women's domestic work and the participation of Indigenous peoples in the war effort, the very fabric of the society was altered. By reviewing the lived experiences and first personal narratives within the larger historical record it becomes clear that the Great War truly transformed the lives of every Canadian, even those in rural northern regions. This article is part of a special collection of papers originally presented at a conference on "The North and the First World War," held May 2016 in Whitehorse, Yukon.
\end{abstract}


There is much to hear in the voices of Canadians that resonate through time in the audio record. The voices of men, women, and children of varied backgrounds, who lived the experience, is perhaps the goal, or the purest source a historian (at least a social historian) can obtain. The "voice" as a historical source, however, is variable and challenges historians to formulate accurate interpretations, and sometimes the intimacy of the recorded voice can overpower a researcher's objectivity. Indeed, in her book Sensing Changes (2010), Joy Parr shows that human memories integrate all the experienced senses, and as historians we should lift our eyes off the written page to see, hear, and perhaps touch the past "embodiment" ${ }^{1}$ of lives lived.

When dealing with audio records, historians must include the documents, images, and newspaper advertisements of a period to flesh out the voices that the audio record brings to life. The phrase "to give voice" implies a certain advocacy in the individuals from the previous generations when applied to historical research. Perhaps a more appropriate way of using audio records is to recognize them as access points to an "audible past," to use Jonathan Sterne's phrase, which is one of the truest connections to personal memory. ${ }^{2}$ However, I do not think that the sound and audio recordings are the best way, or even preferable way, to present histories since there are always filters, editors, and technologies that get in the way between the vocalized memories and the researchers who listen. The following discussion represents the voices of northern British Columbians as their lives intersected with perhaps the most significant historical event in the early twentieth century - the Great War.

The term the "Great War" better reflects the effects that, according to Tim Cook, "hollowed out" Canadian society through the "unlimited war." ${ }^{3}$ The story of this war rolled through generations of Canadians, colouring and influencing major life decisions. The Great War tainted the lived experiences of those who came to this land with such hope and promise. Even the most remote regions of northern British Columbia were deeply affected by the Great War. The Provincial North was, and to some remains, a remote region. The following audio excerpts show that this war touched the lives of northerners, but the several documentary sources also illustrate that the written word, as first-person narratives (autobiographies), can be as powerful as the spoken word, and gives researchers a wide base on which to draw. 
So who was living in northern BC at the outbreak of the war in August 1914? It is hard to say exactly because of the fluid nature of the northern BC population: construction workers for the Grand Trunk Pacific Railway, labourers in the few mining projects in the most remote regions such as Atlin or Stewart, and the seasonal or temporary workers of the fishing industry and canneries. Indigenous people were not included in the general numbers, but according to the 1911 census just under 20,000 people lived in northern $\mathrm{BC} .{ }^{4}$ This was less than $7 \%$ of the total provincial population.

Prince Rupert, on the northwest coast, was considered the only urban centre in the North, with a population of almost 4,200..$^{5}$ The BC provincial government had just begun the first comprehensive survey work in the Peace River and Northeast regions when the war broke out. Historical researcher Jay Sherwood wrote that the Great War radically disrupted agriculture, and mineral and forestry development. The first year-long surveys were completed in November 1914 and, as Sherwood explains, the "information collected in these two extensive explorations were filed away and forgotten in the shadow of the Great War."

The population had increased with the newcomers entering the region using the new transcontinental rail link as well as the oceangoing passenger vessels along the coast. When the Grand Trunk Pacific Railway was completed through to Prince Rupert (Metlakatla) in the spring of 1914, there was much promise of rapid growth to the region from this project. Real estate speculation, that went with every Canadian railroad construction, drove up the cost of real estate along the line, but the true construction costs and servicing made the line unsustainable, and the prolonged war drove the line into bankruptcy. Prince Rupert was a regional hub but also a terminal where some locals would spend periods of time over winter, rather than upcountry on their homesteads.

After war was declared in August 1914, some of the earliest enlistees from northern BC were recent British newcomers, "remittance men" who for various reasons had come to Western Canada-sometimes sent out by families. Remittance men were often younger sons of wealthy families, who were sent abroad to find fame and fortune, or simply to be out of the public eye back home.

Bea Williscroft, who grew up in northwest BC and was a young woman at the time of the war, described some of these men in an interview with CBC broadcaster Imbert Orchard in 1962. In the following segment, Williscroft ends with a comment about Rene Degville who lived on a piece 
of land outside of Telkwa near Tyhee Lake. This is an excerpt from the program Living Memory, aired in 1962:

Williscroft: You know there were a lot of people there who were well educated and had lots of talents. Looking back on it now [pause]-how they happened to get up there, wonder just why.

Of course there were a lot of remittance men, families had bought properties for them or pieces of land and so on. They were living out there in different parts and some of them making a go of it and others taking a look at the land and deciding to let it stay where it was and going into town to see what they could do then. Ah, you see during the war many of these young chaps left us when war broke out. All these young Englishmen who were there. And there were quite a number of them in the valley (Bulkley). And Degville went. After the war I think he was doing illustrations for the Bystander in London. ${ }^{7}$

The full two-hour recording of the interview between Orchard and Williscroft is held in the BC Archives. In the complete unedited recording, Bea Williscroft goes into much greater detail about her memories of the Great War:

I remember one of the things that brought the war home to me was, suddenly was when, um we were, when it was declared of course, we heard it over the telegraph line you see, we didn't get papers twice or three times a week. And of course they were several days old when we got them.

But we heard that this war had been declared and we were in Telkwa at the time.

And all of these people around said it would be over in a month or six weeks, couldn't possibly last.

And all the young Englishmen around, promptly decided to go back home and join their father's regiments, and join up anyway.

This one young chap, Guy Thorpe, had been visiting his uncle Thorpe and Hoops had a real estate firm - real estate and machinery and that sort of thing in Telkwa at the time. ... I happened to be going down to spend a few days in Hazelton, and I went down on the same train that Guy Thorpe went on his way to enlist. And um, it seemed to 
me that it was just - that was in August and he was killed before Christmas.

And it brought it home more than anything else to me, you know because he was the first person I knew who was killed in the war. And it seemed to me that it was just a few days before that I had been travelling down on the train that he had [travelled] on. ${ }^{8}$

Documents, too, provide that intimacy and immediacy of one moment in time. The voice of a young Irish homesteader, who enlisted in 1916, comes through in his written prose and letters home. Twenty-two-year-old Irishman William Lowry wrote to his mother from his homestead near the Bowron River, near present day Quesnel, that he had spent several weeks in Prince Rupert during the winter of 1914-5. Lowry is the first example of a young enlistee who, as a new Irish newcomer, typifies a circular journey from the old country to the wilds of northern BC, back to the Europe for the war effort, and then a return to BC. We can assume that enlistees who signed up in Canada, like Lowry, had to return to Canada until they were discharged from the Canadian military in order to receive pay, medical treatment, and to avoid being charged with desertion. William Lowry's letters are available on one of the many digital sites of resources for historical studies featuring the First World War. ${ }^{9}$

Lowry's first letter, dated November 1915, shows the uncertainties of one young man at a time of war, while he lived in the wilds of northern BC. He wrote of his experiences to be "a fine and sportsman like life, but rough and trying." ${ }^{10} \mathrm{He}$ wrote the "war has destroyed all professional work here" and his prospects of making much needed money as a surveyor were nil. Even trapping for furs had dried up as he added "the war [had] depreciated fur in value," as well. This was confirmed in a May 1916 edition of the Omineca Miner newspaper where it was reported, "There has been a considerable fall in the price of furs, and trappers and Indians realizing far less for their catches than they obtained earlier in the season."11

He explained in his letter that he had gained physical strength and fortitude and listed his feats of frontier living as: "Walked 183 miles in seven days, Packed $100 \mathrm{lbs}$ on ... when prospecting, Poled a canoe 100 miles up a river through two canyons, Excavated $2000 \mathrm{cu}$. yards of clay and rock in making a ditch to drain my homestead." Yet in the next sentence Lowry complained that the "loneliness was sometimes terrible" on his Bowron River homestead. The pull of companionship in the armed 
forces was a factor in his reasoning. "I have often been tempted to join the colours and go back, if not to home at least to Europe and the old friends and society."12

William Lowry was keen to get his mother's views and assured her that he would not enlist "without [her] permission." We do not know what Will's mother thought, but clearly Will had his mind made up regardless as he signed up less then three months later at the office in Prince George. His enlistment papers, dated 25 January 1916, state that he was " $5 \mathrm{ft} .91 \frac{1}{2}$," with a dark complexion and black hair and blue eyes. His occupation was prospector, and his religious denomination was written in as "Unitarian." The final date of the attestation paper is 10 March 1916 and his unit was the 102nd Battalion - the Northern BC unit.

At some point in the next six months, Lowry was severely burned in the hands and face in a dugout in France when some explosives "mysteriously caught fire." The next letter, dated 11 November 1916, was written on Lowry's behalf by a "fellow patient." Lowry spent several weeks in France, then convalesced in a Red Cross hospital in England and then again in Quebec, and finally returned to a hospital on Vancouver Island by July 1917. He was finally discharged in the fall of 1917. His last letter from winter was sent from Finlay Forks in northeastern BC. Lowry explained that he managed to find survey work in Prince George and then was hired as an "assistant Forest Ranger for the Peace River District" in the spring of 1918. His hands healed quite well, and while he regained his eyesight he was plagued with vision troubles for the rest of his short life. ${ }^{13}$

William Lowry's letters provide some fascinating insights into, and observations of, the ongoing censorship of his mother's and sister's letters. As he explained, "apparently the [Censor] was puzzled by a phrase which was underlined by him." ${ }^{14}$ Because only Lowry's letters are accessible it is not known what phrases his sister or mother used that confused the government censor so.

Lowry's sister Dorothy, and her love interest in a cavalry soldier, also features in his letters. He opined that some Canadian men talked up their "property, mines, and ranches as it was overwhelmed with this result: It secured for them wives." He added that the young women who had "come out from England" and made the trek with their new spouses were "not having the life which they expected to lead. Of course the people in the Old Country 'fall' for that big talk very easily. On the other hand there are many fine fellows in the Canadian Army-18 carrat gold they are." ${ }^{15}$

Another interesting statistic shows Lowry's observations had merit. In 1911 the ratio of non-Indigenous male to females was 70/30 in the province 
of BC. Ten years later, women were up $11 \%$ for a closer ratio of $58.5 \%$ men to $41.5 \%$ women. It is possible, then, that of the young men who left for war, fewer came back, and many of those who did took advantage of the opportunity to marry women from overseas, and brought their brides back to British Columbia.

Clearly the war did provide opportunities for young men such as homesteaders like Arthur Shelford to meet available women from the home country. According to his autobiography, Arthur Shelford, who was a long time homesteader in the Ootsa Lake region, met at least two young women who served as nurses in England and were willing to consider moving to a BC Central Interior homestead. The first, a "very pleasant V.A.D." nurse he became engaged to at the close of the war in the winter of 1919, "added greatly to the charm of life" and "made [Shelford] more anxious to get back home and fix things up for her to come out too." ${ }^{16}$ After he returned back home in the spring of 1919, to the homestead he shared with his brother Jack and Jack's English bride Safie, Arthur wrote a candid letter to his prospective bride, explaining the challenges of homestead life. She eventually ended their relationship. After a few years or so, Arthur Shelford then contacted another nurse he had met overseas, Millie, who had taken a post in Malayasia. They met in Victoria and were married there in October 1922, and then travelled back to central BC, by boat to Prince Rupert, then train to Burns Lake, then automobile and open buggy, retracing a similar route that Arthur had travelled to enlist six years before.

Shelford explained in his interview with Imbert Orchard that, although he walked over $70 \mathrm{kms}$ from the Wisteria homestead, Dr. Wrinch of Hazelton almost deemed Shelford unfit for active duty.

Imbert Orchard: Gradually their farm began to take shape. Then came the war.

Shelford: In 1916, I enlisted and then went overseas.

The thing that amused me was the fact that when Dr. Wrinch of Hazelton examined me, he wanted to turn me down for flat feet.

Well I said, "What a - what flat feet implies for a soldier?"

He said, "Well you cannot march."

I said, "I walked forty five miles out to the railway in 24 hours to come out here to enlist." But he said, "You couldn't walk the next day."

No but I did manage to hobble 30 miles over the $\mathrm{T} \ldots$ to Telkwa. 
He said, "Well I guess I better pass you then."

And to think that a man like myself couldn't march with flat feet. During the first year in our country, I walked over eleven hundred miles. ${ }^{17}$

The role of Indigenous men and women from northern BC in the Great War remains largely relegated to the margins of the historical record. Even in the audio record there is nothing of note. However, some there is some mention in contemporary primary sources.

Long-time BC pioneer C.F. Morison wrote in 1919 that, "The Indians are now to cease being wards of the Government and are to be enfranchised and made full citizens of the Dominion of Canada, in return for their great service during the 'Great War,' the Indians of Canada having furnished three thousand men to the Canadian Army." ${ }^{18}$ In actuality, it was close to 4,000 Indigenous men and women who served overseas but Morison wrote this shortly after the war finished. He remembered one Indigenous worker on the Collins Overland Telgraph construction (1866-67), Roger Pearson, who "gave his only son in the Great War."19 While available documentary evidence of Dan Pearson is sparse, he and three other young men are remembered on a plaque in the village office of Metlakatla on the Northwest Coast. According to a short article written by high school teacher Dianne Rabel of Prince Rupert, Dan Pearson was awarded the Military Medal for his actions "at Hill 70 in August 1917. He died a few months later from pneumonia." 20

It is not clear why these men might be missing from the Prince Rupert cenotaph. No doubt they were remembered by family and friends in their respective communities, including old-timers like Charles Morison. Some Indigenous men (of Haida Gwaii) obtained work in the forest industry, with the demand for spruce trees, but many jobs were seasonal and also affected Indigenous fishing and trapping rights. ${ }^{21}$

Arthur Shelford does not mention Indigenous servicemen by name but instead explained how practical Indigenous methods of packing were adopted by the Canadian forces-for example, the tumpline, "a band of soft-tanned leather, broad in the centre to fit over the top of the forehead" to assist in the packing of heavy loads. The weight of "boxes of ammunition ... to the Front Line service," was too cumbersome for the pack board, which as Shelford describes, was "in general use in outlying areas in British Columbia." 22 The use or perhaps re-use of the tumpline technology might not have been exclusively of Indigenous origin, but 
it does show how the old practical skills were exceedingly useful even though this was a war of rapid technological change.

Indigenous women, too, contributed to the cause through their manual labour. In March 1916, for example, it was reported that the Hazelton ladies of the Red Cross made 1,400 surgical dressings and raised \$321. "The knitting of socks" and sewing pajamas for soldiers in hospital was underway. "Splendid assistance is being received from [district] Indian women and girls, who have turned in seventeen pairs of well-knit socks in nine days." ${ }^{23}$

Martha Boss (Mattie), who was born in Barkerville and grew up on the north coast, wrote: the "Indian women at the coast towns were shipping moss out from muskeg swamps, to be used as surgical dressings in the war." Mattie added that this fact "sounds like ancient history, but at the time these industries ranked important." 24 The demand for sphagnum moss increased as the war continued because of the shortage of cotton. The moss was promptly studied by experts who found that the rate of absorbency was significantly higher; by 1918, like other northern regions of Europe, coastal British Columbia and Nova Scotia provided the best quality "from the central ponds of sphagnum swamps." ${ }^{25}$ This "labour intensive" gathering of the raw materials, and then later the manufacture of the moss into bandages, fell mainly on the shoulders of women whose "volunteerism" through large social organizations such as the Canadian Red Cross kept the product fairly cheap. ${ }^{26}$

This volunteer work was often difficult and performed in the few hours that a woman in the pioneer North would have for leisure. Mattie Boss noted that in 1916, after she had moved to the tiny community near Terrace, the "ladies were active all that winter at Red Cross work." At the one meeting that she attended, the women were "busy making surgical gowns," and she volunteered to launder them. After they froze stiff on the line, Mattie Boss decided "others had more time and better facilities to cope with the Red Cross laundry." ${ }^{27}$

Women's institutes and Women's Auxiliary as well as the Red Cross and similar agencies, also raised funds through raffles, teas, and other social gatherings that provided significant amounts of cash for the war effort. Much-needed medical supplies, personal items, and, interestingly enough, cigarettes were sent overseas. The social pressure to be involved in the fundraising and volunteer activities must have added a heavier burden in the smaller northern communities such as Hazelton because there were fewer people to draw on. The loyalties of men and women who 
remained in the community must have been subject to constant public scrutiny.

We can see the underlying competition of fundraising activities in the two publications that were operating in Hazelton, the Omineca Herald and the Omineca Miner. There were apparent tensions between church groups (Ladies Aid), and the Red Cross and the "Soldiers Aid Fund" that helped fill the basic needs of local boys overseas. Even books and magazines were sent overseas to keep the Hazelton men informed and boredom at bay. As explained in the Omineca Miner: "Nine out of ten letters received by the Soldiers Aid [committee] declare with gratitude the reading material sent periodically ... is received by our lads at the front, in hospital, etc. One soldier ... declares he read 'The Miner' four times over to make sure that he had overlooked nothing." 28

The Canadian Patriotic Fund ${ }^{29}$ also listed the contributions from local communities in the Hazelton newspaper. This fund was part of a much larger effort by the federal government to supplement the expanding military budget. Even so, the mineral companies who still operated mines in the region contributed. For example, the Babine Bonanza Mining and Milling Co. donated $\$ 30$ and the Roche de Boule Mine a sizeable \$187.60. Indigenous villages also made financial contributions to this particular fund, such as the Wetsuwit'en community of Hagwilget, which donated $\$ 32.50 . .^{30}$ It is not clear how the Soldiers Aid or Patriotic funds were administered in the Hazelton region, although the Soldiers Aid fund appears to have been created to meet the basic needs of local enlistees.

This never-ending demand for basic supplies as well as luxury items also underlines how all-consuming and ever present the Great War became: even in northern British Columbia the war touched every aspect of the lives of average Canadians. Another long-time resident, Vicky Simms, said that in the small town of Hazelton, the enlistees volunteered "almost to a man from that little town." Sims continued:

The war came, and just ruined everything. All those boys, were killed overseas, our intimate friends you know. My husband's (Pat Aldous] partners; his account and all. [Hazelton, BC] was a changed place [and] the war just ruined everything. ${ }^{31}$

William Lowry complained in a letter to his mother dated October 1917 that the prices of "dry goods" were over 80\% higher than before the war. "The cost of living has gone sky-high, in Canada and States. Flour 
costs more here than in England," he wrote..$^{32}$ One Hazelton newspaper ran advertisements, large and small-in-between stories of the war in Europe - that read "EAT LESS BREAD" on every one of its four pages. ${ }^{33}$ Floyd Frank, who was a child during the war, remembered that wool, even for long underwear, was impossible to get because "wool was reserved for army use and we kids suffered from the cold in winter as a result." ${ }^{34}$

Meanwhile, Mattie Boss described in detail the financial impacts as the war dragged into the second year. Her husband, who dealt in lands and real estate, had to close up his office in 1915. "Times were awful," she wrote. "Immediately war was declared, and the payments stopped and the land business was done for." She remembered, "thirteen city real estate firms closed, only leaving half a dozen well established pioneer land offices doing business." ${ }^{35}$ In Atlin BC, shortages of labour, explosives, and financial investments squeezed the life out of the smaller mines. ${ }^{36}$

When conscription came in late 1917, it led to a shortage of skilled labourers at home. Even newer farm communities in the Bulkley Valley felt the dramatic losses of wartime depopulation. Local historical researcher Lynn Shervall wrote: "Reports of crop losses due to labor shortages were numerous during the war." At one point in July 1918, valley farmers actually passed a resolution calling upon the authorities to "close down all non-essential work, including quartz and coal prospecting and road work for the harvest months," thereby enabling workers in these areas to labour in the fields.$^{37}$ Further, according to Shervall, even established farmers had to explain in a tribunal why they should not be sent overseas. The labour shortage was so acute that the publisher of a local newspaper volunteered himself and his staff to get the harvest in. ${ }^{38}$

Not only did the goods go to the Hazleton and northern boys in active duty, but all aid efforts were reported in the newspaper. The monetary contributions of each person and group were listed, as were sometimes the goods that were sent overseas. In the summer of 1916 it was reported:

Many letters from Hazelton men at the front have been received by the Soldiers' Aid Committee. The boys are all appreciative of the work the Hazelton people are doing through the committee, and their communications show that they are proud of the town they hail from. Their requirements are invariably of the most modest character and the committee has so far experienced no difficulty in supplying them, although further subscriptions will be welcomed by R.E. Allan, the secretary. 
The short article went on to report the list of current injured soldiers, and reported the contributions of individual donations (Dr. Ardagh \$4.10, Mrs. R.E. Allen $\$ 1$, and more) for a grand total of $\$ 111.20 .{ }^{39}$

By December 1917, the same newspaper, the Omineca Miner, was running one large ad for three separate agencies: The Canadian Patriotic Fund, the Canadian Red Cross, and the Soldiers Aid and Employment Committee (see Fig. 1). Besides the brief explanation of each local and national organization, what is most significant about the advertisement are the one-liners at the top and bottom of the page: "If you can't fight you can at least stand behind the man who fights for you ... and then at the bottom of the page, "Some can fight, some can work or pay. ALL CAN SERVE." ${ }^{40}$

Letters received by family members with "news from the front" were also shared every week. Every letter received was promoted, as well as contributions reported. The reports indicate that, to the servicemen, letters from home were extremely important. The soldiers shared the news of their home communities with friends and strangers who knew nothing of northern BC.

Hazelton (Gitanmaax), at the confluence of the Skeena, Bulkley, and Kispiox rivers, was long a centre for trade and a cultural hub to some degree. Even after the war, the cultural and social exchanges continued. Hazelton tried to keep up the needs and demands of news from and about the war in Europe. The war was a central topic in essentially every issue of the Omenica Miner between 1914 and 1918.

In the early stages of the war, the Omineca Miner publisher, R. Macdonald, reported on the enlistment efforts and, increasingly, on the coverage of the battles in Europe. There continued a column for local comings and goings of prominent citizens, such as "R.G. Mosely returned from Prince Rupert this week, Mrs. Moseley has gone to Seattle"; "Geo. Soudack, the fur buyer is in town"; and so on. ${ }^{41}$ But this too incorporated the war as a topic: "George Imlay, a former member of the staff of R.S. Sargent Ltd. is now a sailor on the U.S.S. South Dakota."

Northern women serving overseas were also mentioned in the newspaper including Eva Mae Hogan, the daughter of a Church of England minister and missionary, who enlisted as a "graduate nurse" at the age of thirty-six. Her father had died some years before and "May" had gone to live with her mother in Hazelton and work at the hospital in one of the first nurse-training schools in northern BC. Hogan enlisted in May 1917 and by December, as the Omineca Miner reported, she was 
"nursing at the front" and sent her mother a "souvenir in the shape of a German steel shrapnel helmet." 42

Mattie Boss was a childhood friend of May Hogan and was in Victoria for a social gathering in the fall of 1914 for northern fellows, many of whom were lifelong family and friends. She remembered the younger fellows were full of enthusiasm, whereas the older men were more skeptical, cautious, and reluctant. She wrote: "The night before the northern boys left for overseas, mother entertained them with a party. The younger fellows were very jubilant at going to Europe, but the older men were serious. ... Donald Moore, of Cassiar Cannery, remarked that the young men had "no idea of what they were getting into ... . Lionel Crippen, always the life of the party, was going to bring back a German scalp if a certain young lady would accept it and she [unidentified] young lady would do well to bring back his own scalp. She was sorry afterwards and said she never could [imagine] anything happening to "Crip." ... The last we heard of him he had lost his gun and was throwing granades. He and Don (Moore) were killed early in the game." ${ }^{43}$

Mattie's two brothers signed up, with one serving in the Navy and the other in the air force. "Many of our friends never returned and others married girls abroad and settled in the old country. Others came back badly gassed and sick, but thankful to be home." By 1916, the Bosses had returned to the northwest region after Hank got seasonal work in the post office and as a fisheries officer at Lakelse Lake near Terrace, which Mattie Boss described as a "stump town."

Another local family who lived in the Terrace region, the Franks, had four children. Floyd Frank was an adolescent during the war years and he wrote in his memoirs of how the demand for Sitka spruce in the construction of airplanes was in great demand in the later years of the war. He said "the early type planes ... were mostly biplanes and triplanes made from lightweight wood and wire for struts and braces." 44 The lower Skeena River valley and Queen Charlotte Islands (Haida Gwaii) were the main sources of spruce in British Columbia, and were subject to the British government procurement regulations.

The harvesting and new technologies behind this demand are perhaps more accessible to historical research, but when considering the northern voices and war culture this topic is also significant. In the summer of 1918, a young man, possibly a university student from Vancouver by the name of Daniel Hatt, worked as a logger as part of the war effort on Haida. He then returned home and wrote a series of poems or "songs," as he called them, in homage to this wartime adventure..$^{45}$ Published in 1919, Hatt's 
collection, Sitka Spruce: Songs of the Queen Charlotte Islands, expressed one young man's nostalgic memories of the war even though he did not fight at the front. His collection of poems also points to how the war instigated pivotal industrial changes in the more remote regions of BC. On the title page, Hatt dedicated his work, "To the Aeroplane Spruce Loggers of the Queen Charlotte Islands, with whom it was the writer's privilege to live and labor as 'Y Man' during the summer and autumn of 1918, for these Songs are now dedicated, as a humble tribute to the splendid part play[ed] by these men in a most important war industry." 46

Daniel Hatt, and more urban dwellers, began to see the potential of northern $\mathrm{BC}-$ not as a homeland, but rather as a storehouse for natural resources. The population boom that was anticipated with the building of the Grand Trunk Pacific Railway largely fizzled out, and homestead preemption that had been started before 1914 stagnated. The war touched every aspect of life in northern BC; from the newcomer soldiers to the families, farmers, and miners who stayed behind. The underlying opinion seems to be that, as voiced by Vicky Simms, the war "ruined everything." All the promise of regional wealth and development fell flat because of the war. Even in an isolated northern region, every aspect of life was altered. From the stresses of enlistment by family members, to the lives lost at the front, to the unending and guilt-driven fundraising activities, to the high cost of goods, life must have been unbearable sometimes. The voices of northern British Columbians during the Great War serve to remind us, though, that beyond the sadness and grief there is a resiliency to be found in those who pushed through, survived, and came back to again make northern BC their home.

\section{Author}

Maureen L. Atkinson has lived in northwestern BC for twenty years, and is a sessional instructor at the University of Northern British Columbia and $\mathrm{a} \mathrm{PhD}$ candidate in history at the University of Waterloo.

\section{Notes}

1. Joy Parr, Sensing Changes: Technologies, Environments, and the Everyday, 19532003 (Vancouver: UBC Press, 2010), 1-23.

2. Jonathan Sterne, The Audible Past: Cultural Origins of Sound Reproduction (Durham: Duke University Press, 2003).

3. Tim Cook, "Keynote presentation," The North and World War One, Whitehorse YT, 10 May 2016.

4. Jean Barman, The West Beyond the West: A History of British Columbia, 437. 
5. Barman, 443

6. Jay Sherwood, In the Shadow of the Great War: The Milligan and Hart Explorations of Northeastern British Columbia, 1913-1914 (Victoria: Royal BC Museum Corp., 2013), 12.

7. Living Memory, CFPR/CBC Radio Archives, Prince Rupert Archives, CD 81, cut 5 (airdate, June 1962).

8. Imbert Orchard, Bea Williscroft, Imbert Orchard Collection, British Columbia Archives (Victoria) T1208:0001 \& 0002 BC Archives, recorded 1962.

9. Lowry's letters are available on a website created for Vancouver Island University (Nanimo, BC), accessed 28 Jan 2016, http://canadianletters.ca/ content/document-4012

10. William Lowry, personal letter, 1 Nov 1915.

11. Omineca Miner, 6 May 1916, 1.

12. Lowry, Ibid. 1 Nov 1915.

13. William Lowry died in 1940. See Obit: "Forestry man dies at Pouce Coupe," Prince George Citizen, Thursday, 25 Jan 1940, accessed 20 Feb 2016, http:// pgnewspapers.pgpl.ca/fedora/repository/pgc:1940-01-25/-/Prince\%20 George\%20Citizen\%20-\%20January\%2025,\%201940

14. William Lowry, Personal correspondence, 27 Jul 1917.

15. William Lowry, Personal correspondence, 12 May 1918.

16. 16 Arthur Shelford (with Cyril Shelford), We Pioneered (Victoria: Orca Book Publishers, 1988), 169.

17. Living Memory, "Arthur Shelford," CBC/CFPR Radio archives, Prince Rupert Archives, CD 81, track 6. (Airdate 1962?)

18. C.F. Morison, Reminiscences of British Columbia from 1862, By a Pioneer of the Northwest Coast. Unpublished manuscript, BC Archives, 88-89.

19. Ibid., 28.

20. Diane Rabel, "Aboriginal Soldiers from the North Coast," in From the West Coast to the Western Front: British Columbians and the Great War, ed. Mark Forsythe and Greg Dickson (Vancouver: Harbour Publishing 2014), 113.

21. Roy and Thompson, Promises, 109-10.

22. Shelford, We Pioneered, 128.

23. “Red Cross Doing Excellent Work," Omineca Miner, Saturday, 11 Mar 1916.

24. Martha (O'Neill) Boss, A Tale of Northern British Columbia: From Cariboo to Cassiar, Unpublished Manuscript, BC Archives (circa 1950), 213

25. Natalie N. Reigler, "Sphagnum Moss in World War I," Canadian Bulletin Medical History, Volume 6, (1989), 32

26. Reigler, 32.

27. Boss, 209.

28. Omineca Miner, Saturday, 29 Sep 1917, 1.

29. For more on the Patriotic fund see "Canada and the First World War: The Canadian Patriotic Fund," Canadian War Museum, http://www. warmuseum.ca/firstworldwar/history/life-at-home-during-the-war/ the-home-front/the-canadian-patriotic-fund/ 
30. "Patriotic Fund Still Growing," Omineca Miner, Saturday, 20 May 1916.

31. "Vicky Simms," (audio recording), Imbert Orchard Collection, BC Archives, T311:0001.

32. Lowry, Personal correspondence, 4 Oct 1914.

33. Omineca Miner, 24 Aug 1918.

34. Floyd Frank, My Valley's Yesteryears (Terrace: Self published, 1991), 74.

35. Boss, 203.

36. Christine Frances Dickinson and Diane Solie Smith, Atlin: The Story of British Columbia's Last Gold Rush (Atlin: Atlin Historical Society, 1995), 94, 104 \&107.

37. Lynn Shervall, Smithers: From Swamp to Village (Town of Smithers, 1981), 26.

38. Dickinson et al., 28.

39. Omineca Miner, "Soldiers' Aid Fund," 17 Jun 1916.

40. Onimeca Miner, Saturday, 15 Dec 1917.

41. Omineca Miner, Saturday, 9 Feb 1918.

42. Omineca Miner, 15 Dec 1917.

43. Martha (O'Neill) Boss, Tale of Northern British Columbia, 79.

44. Frank, 74.

45. Daniel E. Hatt, Sitka Spruce: Songs of Queen Charlotte Islands (Vancouver: R.P. Latta Publishers, 1919). It is not known whether Hatt's compositions were set to music.

46. Hatt, 1919. 